\title{
Physico-Chemical and Organoleptic Perspectives of Ginger Marmalade
}

\author{
Saira Tanweer ${ }^{1,2^{*}}$, Tariq Mehmood ${ }^{1,2}$, Saadia Zainab ${ }^{3}$ and Aamir Shehzad ${ }^{1}$ \\ ${ }^{1}$ National Institute of Food Science and Technology, University of Agriculture, Faisalabad, Pakistan \\ ${ }^{2}$ Government College University Faisalabad, Sahiwal Campus, Sahiwal, Pakistan \\ ${ }^{3}$ Department of Food Engineering, University of Agriculture, Faisalabad, Pakistan
}

\begin{abstract}
Herbal plants have been recognized as effective medicinal agents. Medicinal plants are growing massive importance towards the health of individuals and communities. Owing to phytochemical perspectives functional/nutraceutical foods are scoring more attention of the nutritionists. In this scenario, ginger is gaining importance due to its accessibility, low cost and allied therapeutic claims. In current investigation, functional and nutraceutical product i.e. marmalade were prepared after the addition of ginger against control to increase its health promoting ability. For marmalade prepared with $7 \%$ ginger powder $\left(T_{1}\right)$ and $3 \%$ ginger extract $\left(T_{2}\right)$ appeared to have non-significant impacts on color tonality, in total soluble solids, pH, acidity and brix. The substantial enhancement in brix was noticed during storage from $68.14 \pm 2.34$ to $69.20 \pm 2.49$ at 0 to $60^{\text {th }}$ day, respectively whereas $\mathrm{pH}$ decreased from $3.68 \pm 0.13$ to $3.45 \pm 0.12$ and in the opposite pattern acidity increased from 0.60 \pm 0.02 to $0.74 \pm 0.05 \%$. Sensory evaluation was also assessed to evaluate the color, flavor, taste, spread ability and overall acceptability of marmalade. Means squares for sensory evaluation of marmalade showed that all the parameters remained non-significant within the treatments and storage except spread-ability and only flavor and taste changed significantly with the treatment. During storage, scores assigned to taste of decreased from $7.36 \pm 0.29$ to $7.24 \pm 0.25$. The overall acceptability was highly admired by nutraceutical extract based ginger marmalade. Conclusively, the findings of current exploration showed that gingerol present in ginger did not impact any deleterious outcomes on the sensory response.
\end{abstract}

Keywords: Ginger extract; Physico-chemical; Ginger marmalade; Gingerol

\section{Introduction}

Edible plants have the abundant extent of naturally occurring antioxidant, especially spices and herbs. Many researchers have clinched antioxidant potential of plants specially spices [1]. Food is a rich source of phenolic compounds (flavonoids, phenolic acid and alcohols) that show excellent antioxidant activity [2]. Ginger (Zingiber officinale) belonging to the family Zingiberaceae is native to temperate climates, particularly China and South Eastern Asia especially India, is propagated through rhizome. It is one of the vital and cost effective crops of Nigeria due to its essential oil and oleoresin levels, grown mainly on lucrative point and can be exported in large quantities due to its sharp flavor; pungency and high oleoresin content [3].

Ginger (Zingiber officinale) belongs to the family Zingiberaceae that has a perpetual tuberous root or rhizome [4]. It is cultivated in South East Asia and then spread extensively around the world. There are various investigations related to composition as well as the biological activities (antimicrobial, antioxidant, and immune enhancing perspectives) of ginger extracts has been carried out [5]. It is used in several food products as flavor and condiments for giving them essence [6]. Owing to provide all these properties, ginger rhizome is used from many centuries. Fresh ginger is also being used in food preparation aid [7].

Product development phase is not only delimited to form distinct food possessions but also embraces new food product transmission, line deferral and reformulating of the previous existing items. Among different supplemented and fortified food systems, the baked along with confectionary products provide an excellent opportunity to integrate food-grade portions from non-traditional food fonts [8]. In the present era, consumer focuses on more freshly prepared foods that are indirect demand of natural foods having high antioxidants. Herbs and spices used in routine are excellent source of polyphenolic contents. These constitutes have high antioxidant potential. This ability of herbs marked them crucial in competition with synthetic antioxidants with additional health benefits [9]. A major challenge that is food industry facing, is to produce the food product that contain health protective diet. To achieve this task food industries are focusing on the functional foods that are inordinate origin of antioxidants $[10,11]$.

Currently, the pharmaceutical food products are developed with additional health welfares based on their functional bioactive ingredients. The products that are made with additional benefits beyond the nutritional value are commonly called functional foods. Thereby the term functional food is really used by the public, but is not yet commonly known among users [12]. However, there is a constant flow of new product initiators in food product development center which claim to be "functional foods" or "foods with additional strength welfares" but only a few of them proved to be successful [13]. Food industries are nowadays encrusting enormously challenges from which the most imperative is around the necessity to develop new products which can subsidize to the customer's aspiration for a health-defensive diet and the industries are successful to achieve this task because they mainly focused on the natural foods that have antioxidant potential [14].

In confectionary products as jam, jellies and marmalade sugar helps in thickening that further form gel structure of product. It also assists as a preserving agent, subsidizes to the essence and flavor of the jam product and has a stiffening influence on fruit properties. Beet and sugar cane both have same importance in confectionary

*Corresponding author: Dr. Saira Tanweer, National Institute of Food Science and Technology, University of Agriculture, Faisalabad, Pakistan, Tel: 9233351435 65; E-mail: sairatanweer1116@gmail.com

Received July 19, 2018; Accepted August 31, 2018; Published September 05, 2018

Citation: Tanweer S, Mehmood T, Zainab S, Shehzad A (2018) Physico-Chemical and Organoleptic Perspectives of Ginger Marmalade. J Food Process Technol 9 : 752. doi: $10.4172 / 2157-7110.1000752$

Copyright: (c) 2018 Tanweer S, et al. This is an open-access article distributed under the terms of the Creative Commons Attribution License, which permits unrestricted use, distribution, and reproduction in any medium, provided the original author and source are credited. 
products. Mostly extra pectin is added in marmalade of those fruits that have less content of pectin in it. In some foods as apple, barriers and grapes natural pectin is present that improves its quality however herbs like ginger is very poor in pectin content [15]. Commercially prepared pectin can be used in any food product. It is manufactured from fruits and is available in both liquid and powder form that are not exchangeable. It is essential to mark an excellent balance between sourness and sweetness, which is frequently succeeded by adding an assortment of sugar with citric acid. This mixture gives same timeintensity curve because these both produce identical sweet and sour taste at their maximum level of use [16].

Sugar and sugar sweeteners both are nutritive in nature because on consumption they give energy. Being carbohydrate in nature, sugar provides $4 \mathrm{kcal} / \mathrm{gram}$ but sugar alcohols provide an average of $2 \mathrm{kcal} / \mathrm{g}$. Conflicting to their name, the new formed sugar alcohols are neither sugars nor alcohols in nature. Sugar alcohols are also fall in the category of carbohydrates. Chemical structure of sugar alcohols resembles with both sugar and alcohol. Products manufactured with sugar alcohols are labeled as sugar free food products substitute full calorie carbohydrates i.e. sugar [15]. Sugar alcohols are also identified as GRAS or food additive. Mostly used sugar alcohols are sorbitol, isomalt, lactitiol, maltitol and erythritol. Sorbitol is classified as GRAS while other all are used as food additives. Glycemic index in body can be reduced by use of sugar alcohols. Other properties of sugar alcohol are prevention from dental cavities accompanied by depressing calories intakes [17]. Five FDA approved non-nutritive sweeteners are acesulfame K, aspartame, neotame, saccharin and sucralose. All of these are regulated as food additives and evaluated on the basis of their safety, sensory attributes and constancy in a number of food products. They are mostly used in combination of They are often combined with other nutritive and non-nutritive sweeteners to improve volume and desire flavor that they cannot obtain separately. FDA has been established an acceptable daily intake (ADI) for each food additive. The ADI is the quantity of food product that can be expended in routine for life time without any risk to the body [18].

Hedonic response is carried out to evaluate the ability of human replies to estimate the physico-chemical characteristics of food e.g. appearance, texture, color, aroma, fragrance, touch and taste. To commercialize these experimental designed foods these required characteristics must be achieved. An important factor that must be taken into consideration is the baking losses of antioxidant perspectives of the bioactive ingredients that effect taste and flavor of product if stored for longer time. To overcome this problem antioxidants are being used to enhance the benficial aspects. Synthetic antioxidants are now restricted in various food item due to their carcinogenic effects [19].

During product development two products namely ginger patties and ginger marmalade was prepared using functional and one best selected treatment from conventional solvent. Raw material used in patties preparation comprised of flour, sugar, egg, shortening, baking powder and chicken, onion, ginger, spices for filling; while ingredients for marmalade includes sugar, sweetener, citrus peel, ginger and preservatives were purchased from local market. Some amount of sugar was replaced with artificial sweetener in marmalade. A control sample without ginger powder or extract was also prepared for comparison purpose. In both products, some extra amount of functional and nutraceutical fractions were added in $\mathrm{T}_{1}$ and $\mathrm{T}_{2}$, respectively considering baking losses (Table 1).

\begin{tabular}{|l|l|}
\hline & Ginger Marmalade \\
\hline $\mathbf{T}_{1}$ & Control \\
\hline $\mathbf{T}_{2}$ & Marmalade with ginger powder (7\%) \\
\hline $\mathbf{T}_{3}$ & Marmalade with ginger extract $(3 \%)$ \\
\hline
\end{tabular}

Table 1: Treatments used in product development.

\section{Material and Methods}

\section{Physicochemical analysis of functional/nutraceutical products}

The prepared ginger patties were evaluated for color, texture and antioxidant characteristics at $0,24^{\text {th }}, 48^{\text {th }}, 72^{\text {nd }}$ and $96^{\text {th }} \mathrm{hr}$. Nonetheless, the ginger marmalade was analyzed for $\mathrm{pH}$, color, acidity, brix and spread ability at $0,15,30,45$ and 60 days intervals.

The color and texture parameters were measured using the method of Lara et al. [20]. Antioxidant potential of products was determined by the estimation of total phenolic contents as described by Qiu et al. [21]. Furthermore, total soluble solids of spread were evaluated by digital refractometer (TAMCO, Model No. 90021, Japan). Likewise, the $\mathrm{pH}$ was recorded though calibrated $\mathrm{pH}$ meter (InoLab 720, Germany). Moreover, total acidity of was estimated by titrating the sample against $0.1 \mathrm{~N}$ sodium hydroxide [22]

\section{Color}

The products surface color, $\mathrm{L}^{*}$ (lightness), $\mathrm{a}^{*}$ (-a greenness; +a redness), and $b^{*}$ ( $-b$ blueness; $+b$ yellowness) were measured using CIE-Lab Color Meter (CIELAB SPACE, Color Tech-PCM, USA). The data thus obtained was used to calculate chroma $\left(\mathrm{C}^{*}\right)$ and hue angle [20].

$$
\text { Chroma }\left(C^{*}\right)=\left[\left(a^{*}\right)^{2}+\left(b^{*}\right)^{2}\right]^{1 / 2}
$$$$
\text { Hue angle }(h)=\tan ^{-1}\left(b^{*} / a^{*}\right)
$$

\section{Texture}

Texture of ginger patties was measured using the triple beam snap (three-point break) technique of texture analyzer (TA-HDi, Stable Microsystems, UK). A crosshead speed of $10 \mathrm{~mm} / \mathrm{min}$ with a load cell of $50 \mathrm{~kg}$ was used. Force required to break products individually was noted and the average was calculated according to protocol described by Lara et al. [20].

\section{Antioxidant activity}

Antioxidant potential of ginger patties was determined by estimation of total phenolic contents as described by Qiu et al. [21].

\section{Brix}

Brix of ginger marmalade were estimated by Hand Refractometer (TAMCO, Model No. 90021, Japan) at respective storage intervals and interpreted as percent soluble solids $\left.{ }^{\circ} \mathrm{Brix}\right)$.

\section{pH}

The representative marmalade was taken in $50 \mathrm{~mL}$ beaker and $\mathrm{pH}$ was recorded by $\mathrm{pH}$ meter (Ino Lab 720, Germany) following the method of AOAC [22]

\section{Acidity}

The acidity of ginger marmalade was determined during storage by 
adopting the guidelines of AOAC [22]. The selected sample was titrated against $0.1 \mathrm{~N}$ sodium hydroxide $(\mathrm{NaOH})$ solution till persistent pink color.

\section{Hedonic response}

The developed products $\left(T_{0}, T_{1}, T_{2}\right)$ were examined for sensory evaluation using nine point hedonic scale system ranged from extremely liking to disliking (9=like extremely; $1=$ dislike extremely) following the guidelines of Meilgaard et al. [23]. Sensory response of the ginger patties for various traits like color, flavor, texture, taste and overall acceptability was carried out at $0,24,48,72$ and 96 hours while in case of marmalade the trait of texture was replaced with spread-ability. This part of study was conducted in the Sensory Evaluation Laboratory of the NIFSAT, University of Agriculture, Faisalabad.

\section{Results and Discussion}

\section{Physio-chemical analysis of marmalade}

The resultant functional (7\% ginger powder) and nutraceutical (3\% ginger extract) marmalade were evaluated for color tonality, texture as well as $\mathrm{pH}$, brix, brix/acid ratio and acidity during two months storage time.

\section{Color}

Color is one of the vital factors in the acceptance of fruit products such as marmalades that are prepared by heat treatments that altered the color of the final product. Color tonality for any food product includes $\mathrm{L}^{*}, \mathrm{a}^{*}$ and $\mathrm{b}^{*}$, chroma and hue angle values depending upon its lightness, redness or greenish color \& blue to yellow shade. Mean squares resultant qualities of color tonality for marmalade (Table 2 ) showed that treatments have non-significantly affected all color tonality traits while non-momentous difference was observed for storage and interaction. Means relating $\mathrm{L}^{*}$ values of marmalade (Table 3 ) has revealed that maximum value $18.54 \pm 0.73$ and $18.44 \pm 0.72$ were recorded in $\mathrm{T}_{2}$ (marmalade containing 7\% ginger powder) and $\mathrm{T}_{1}$ while minimum $17.56 \pm 0.68$ in $\mathrm{T}_{0}$ (control). It was assessed that $\mathrm{L}^{*}$ value decreased in all treatment as function of storage from $20.22 \pm 0.69$ to $16.42 \pm 0.59$. The $\mathrm{a}^{*}$ values (Table 4 ) of ginger was maximum in $\mathrm{T}_{2} 18.78 \pm 0.73$ and $\mathrm{T}_{0}$ $(18.50 \pm 0.71)$ and it was minimum in $\mathrm{T}_{1}(18.24 \pm 0.70)$. During storage, values for $\mathrm{a}^{*}$ increased from $16.78 \pm 0.58$ to $20.00 \pm 0.72$.

It is conformed from Table 5 that $\mathrm{b}^{*}$ value changed non-significantly as a function of treatment i.e. $1.66 \pm 0.05,1.62 \pm 0.06$ and $1.58 \pm 0.06$ in $T_{1}, T_{2}$ and $T_{0}$, respectively With the passage of time, $b^{*}$ value for all treatments decreased non-significantly that was minimum for $\mathrm{T}_{2}$ $(1.70 \pm 0.07$ to $1.52 \pm 0.05)$. Means depicting the effect of treatments on chroma (Table 6) showed that maximum value $20.13 \pm 0.79$ was recorded in $\mathrm{T}_{1}$, whilst minimum value $18.55 \pm 0.70$ was observed in $\mathrm{T}_{0}$. Likewise, chroma value progressive increased from $17.19 \pm 0.58$ to $20.69 \pm 0.74$. It is manifest (Table 7) that $\mathrm{T}_{1}$ has lowest value $4.57 \pm 0.20$ for marmalade hue angle in contrast to $\mathrm{T}_{0}$ and $\mathrm{T}_{2}$ Storage affected hue angle non-significantly that decreased from $4.95 \pm 0.17$ to $4.94 \pm 0.18$ at the end of storage interval.

The present results are in line with the previous findings of Rababah et al. [24] prepared grape and whole \& grounded raisin in addition to citrus marmalade to check its color tonality. In this they used same quantity in all treatments and suggested that the highest value of $\mathrm{L}^{*}$ was for whole raisin marmalade $(23.1 \pm 1.4)$ followed by grounded raisin marmalade $(19.8 \pm 1.7)$ and lowest for grape marmalade $(17.2$ \pm 1.2 ). The same trend was observed in chroma and $b^{*}$ values that were highest for whole raisin marmalade and lowest for grape marmalade

\begin{tabular}{|c|c|c|c|c|c|c|}
\hline Sov & df & $L^{*}$ value & $a^{*}$ value & $b^{*}$ value & Chroma & $\begin{array}{c}\text { Hue } \\
\text { angle }\end{array}$ \\
\hline Treatment (A) & 2 & $4.36^{\mathrm{NS}}$ & $10.39^{\mathrm{NS}}$ & $0.02^{\mathrm{NS}}$ & $10.39^{\mathrm{NS}}$ & $1.77^{\mathrm{NS}}$ \\
\hline Days (B) & 4 & $21.17^{\mathrm{NS}}$ & $18.04^{*}$ & $0.04^{\mathrm{NS}}$ & $18.09^{\mathrm{NS}}$ & $0.18^{\mathrm{NS}}$ \\
\hline$A \times B$ & 8 & $0.36^{\mathrm{NS}}$ & $0.28^{\mathrm{NS}}$ & $0.43^{\mathrm{NS}}$ & $0.27^{\mathrm{NS}}$ & $0.09^{\mathrm{NS}}$ \\
\hline Error & 30 & 14.66 & 5.28 & 0.11 & 16.32 & 1.00 \\
\hline
\end{tabular}

Table 2: Means squares for color tonality of marmalade.

\begin{tabular}{|l|l|l|l|l|}
\hline \multirow{2}{*}{$\begin{array}{l}\text { Storage intervals } \\
\text { (days) }\end{array}$} & Treatments & \multirow{2}{*}{ Means } \\
\cline { 2 - 5 } & $\mathbf{T}_{\mathbf{0}}$ & $\mathbf{T}_{\mathbf{1}}$ & $\mathbf{T}_{\mathbf{2}}$ & \\
\hline $\mathbf{0}$ & $19.76 \pm 0.67$ & $20.32 \pm 0.69$ & $20.58 \pm 0.70$ & $20.22 \pm 0.69$ \\
\hline $\mathbf{1 5}$ & $18.62 \pm 0.60$ & $19.24 \pm 0.62$ & $19.44 \pm 0.62$ & $19.10 \pm 0.61$ \\
\hline $\mathbf{3 0}$ & $17.38 \pm 0.52$ & $18.02 \pm 0.54$ & $18.96 \pm 0.57$ & $18.12 \pm 0.54$ \\
\hline $\mathbf{4 5}$ & $16.24 \pm 0.61$ & $17.86 \pm 0.68$ & $17.02 \pm 0.60$ & $17.04 \pm 0.65$ \\
\hline $\mathbf{6 0}$ & $15.80 \pm 0.57$ & $16.74 \pm 0.60$ & $16.72 \pm 0.60$ & $16.42 \pm 0.59$ \\
\hline Means & $17.56 \pm 0.68$ & $18.44 \pm 0.72$ & $18.54 \pm 0.73$ & \\
\hline $\begin{array}{l}\mathrm{T}_{0}=\text { (control marmalade) } \\
\mathrm{T}_{1}=\text { (marmalade containing 7\% ginger powder) } \\
\mathrm{T}_{2}=\text { (marmalade containing 3\% ginger extract) }\end{array}$ & \\
\hline
\end{tabular}

Table 3: Effect of treatments and storage on $\mathrm{L}^{*}$ value of marmalade.

\begin{tabular}{|l|l|l|l|l|}
\hline \multirow{2}{*}{$\begin{array}{l}\text { Storage intervals } \\
\text { (days) }\end{array}$} & Treatments & \multirow{2}{*}{ Means } \\
\cline { 2 - 5 } & $\mathbf{T}_{0}$ & $\mathbf{T}_{1}$ & $\mathbf{T}_{2}$ & \\
\hline $\mathbf{0}$ & $16.42 \pm 0.56$ & $17.34 \pm 0.59$ & $16.58 \pm 0.56$ & $16.78 \pm 0.58^{\mathrm{c}}$ \\
\hline $\mathbf{1 5}$ & $17.80 \pm 0.57$ & $17.60 \pm 0.56$ & $17.82 \pm 0.57$ & $17.74 \pm 0.59^{\mathrm{bc}}$ \\
\hline $\mathbf{3 0}$ & $18.56 \pm 0.58$ & $18.24 \pm 0.55$ & $18.76 \pm 0.55$ & $18.52 \pm 0.57^{\mathrm{b}}$ \\
\hline $\mathbf{4 5}$ & $19.68 \pm 0.75$ & $18.88 \pm 0.72$ & $19.94 \pm 0.76$ & $19.50 \pm 0.74^{\mathrm{ab}}$ \\
\hline $\mathbf{6 0}$ & $20.04 \pm 0.72$ & $19.16 \pm 0.69$ & $20.78 \pm 0.75$ & $20.00 \pm 0.72^{\mathrm{a}}$ \\
\hline Means & $18.50 \pm 0.71$ & $18.24 \pm 0.70$ & $18.78 \pm 0.73$ & \\
\hline $\begin{array}{l}\mathrm{T}_{0}=\text { (control marmalade) } \\
\mathrm{T}_{1}=\text { (marmalade containing 7\% ginger powder) } \\
\mathrm{T}_{2}=\text { (marmalade containing 3\% ginger extract) }\end{array}$ & \\
\hline
\end{tabular}

Table 4: Effect of treatments and storage on a* value of marmalade.

however, the movement of a* values was different from this trend. The highest value of $\mathrm{a}^{*}$ was found in grape marmalade and lowest for whole raisin marmalade. Another research conducted by Abdollahi et al. [25] formulated pomegranate jam with the increased amount of sugar as well as quince puree amount by 10,20 and $30 \%$. They reported in that research that the color tonality changes with the change in the concentration of sugar and quince puree percentage. With the increase in quince percentage the value of $\mathrm{a}^{*}$ decreased but the value of $\mathrm{L}^{*}$ and $\mathrm{b}^{*}$ increased with the high percentage of sugar. One of their peers, Yildiz and Alpaslan [26] used different methods to prepare marmalade under classical method and vacuum evaporation method and stated that the $\mathrm{L}^{*}$ value of marmalade varied from $23.40 \pm 0.20$ to $30.20 \pm 0.10$ while the value of $\mathrm{a}^{*}$ ranged from $10.30 \pm 0.10$ to $16.60 \pm 0.20$.

\section{pH and acidity}

$\mathrm{pH}$ is the negative logarithm of hydrogen ion concentration and that is imparted by acid. As the acidity increase there was an inverse proportional decrease in the $\mathrm{pH}$ value during storage. The formation of acidic compounds during storage increases the acidity of marmalade that further decreases the $\mathrm{pH}$ level [27]. $\mathrm{pH}$ and acidity determination is of crucial importance for acceptability of product as it describe the quality of product that changes during processing. Means squares (Table 8 ) regarding $\mathrm{pH}$ and acidity of ginger marmalade have revealed non-significant difference for effect of treatment and interaction of 


\begin{tabular}{|c|c|c|c|c|}
\hline \multirow{2}{*}{\begin{tabular}{|c|}
$\begin{array}{c}\text { Storage intervals } \\
\text { (days) }\end{array}$ \\
\end{tabular}} & \multicolumn{3}{|c|}{ Treatments } & \multirow{2}{*}{ Means } \\
\hline & $T_{0}$ & $T_{1}$ & $T_{2}$ & \\
\hline 0 & $1.64 \pm 0.06$ & $1.76 \pm 0.04$ & $1.70 \pm 0.05$ & $1.70 \pm 0.07$ \\
\hline 15 & $1.62 \pm 0.06$ & $1.70 \pm 0.04$ & $1.66 \pm 0.05$ & $1.66 \pm 0.06$ \\
\hline 30 & $1.58 \pm 0.05$ & $1.66 \pm 0.04$ & $1.62 \pm 0.05$ & $1.62 \pm 0.06$ \\
\hline 45 & $1.54 \pm 0.05$ & $1.62 \pm 0.03$ & $1.58 \pm 0.06$ & $1.58 \pm 0.05$ \\
\hline 60 & $1.50 \pm 0.05$ & $1.54 \pm 0.05$ & $1.52 \pm 0.06$ & $1.52 \pm 0.05$ \\
\hline Means & $1.58 \pm 0.06$ & $1.66 \pm 0.05$ & $1.62 \pm 0.06$ & \\
\hline
\end{tabular}

Table 5: Effect of treatments and storage on $b^{*}$ value of marmalade.

\begin{tabular}{|l|l|l|l|l|}
\hline \multirow{2}{*}{$\begin{array}{l}\text { Storage intervals } \\
\text { (days) }\end{array}$} & \multicolumn{2}{|l|}{ Treatments } & \multirow{2}{*}{ Means } \\
\cline { 2 - 5 } $\mathbf{T}_{0}$ & $\mathbf{T}_{1}$ & $\mathbf{T}_{2}$ & \\
\hline $\mathbf{0}$ & $16.49 \pm 0.56$ & $18.42 \pm 0.63$ & $16.65 \pm 0.58$ & $17.19 \pm 0.58$ \\
\hline $\mathbf{1 5}$ & $17.87 \pm 0.57$ & $19.65 \pm 0.62$ & $17.89 \pm 0.57$ & $18.47 \pm 0.59$ \\
\hline $\mathbf{3 0}$ & $18.63 \pm 0.55$ & $20.35 \pm 0.61$ & $18.83 \pm 0.61$ & $19.27 \pm 0.58$ \\
\hline $\mathbf{4 5}$ & $19.75 \pm 0.75$ & $21.00 \pm 0.80$ & $20.01 \pm 0.76$ & $20.35 \pm 0.77$ \\
\hline $\mathbf{6 0}$ & $20.11 \pm 0.72$ & $21.23 \pm 0.76$ & $20.85 \pm 0.75$ & $20.69 \pm 0.74$ \\
\hline Means & $18.55 \pm 0.70$ & $20.13 \pm 0.79$ & $18.85 \pm 0.73$ & \\
\hline $\begin{array}{l}\mathrm{T}_{0}=\text { (control marmalade) } \\
\mathrm{T}_{1}=\text { (marmalade containing 7\% ginger powder) } \\
\mathrm{T}_{2}=\text { (marmalade containing 3\% ginger extract) }\end{array}$ & & \\
\hline
\end{tabular}

Table 6: Effect of treatments and storage on chroma value of marmalade.

\begin{tabular}{|c|c|c|c|c|}
\hline \multirow{2}{*}{\begin{tabular}{|c|} 
Storage intervals \\
(days)
\end{tabular}} & \multicolumn{3}{|c|}{ Treatments } & \multirow{2}{*}{ Means } \\
\hline & $T_{0}$ & $T_{1}$ & $T_{2}$ & \\
\hline 0 & $5.14 \pm 0.17$ & $4.57 \pm 0.16$ & $5.14 \pm 0.17$ & $4.95 \pm 0.17$ \\
\hline 15 & $5.13 \pm 0.16$ & $4.56 \pm 0.15$ & $5.13 \pm 0.16$ & $4.94 \pm 0.16$ \\
\hline 30 & $5.15 \pm 0.15$ & $4.57 \pm 0.14$ & $5.15 \pm 0.15$ & $4.96 \pm 0.15$ \\
\hline 45 & $5.12 \pm 0.19$ & $4.58 \pm 0.17$ & $5.14 \pm 0.20$ & $4.95 \pm 0.19$ \\
\hline 60 & $5.13 \pm 0.18$ & $4.57 \pm 0.16$ & $5.14 \pm 0.20$ & $4.94 \pm 0.18$ \\
\hline Means & $5.13 \pm 0.20$ & $4.57 \pm 0.18$ & $5.14 \pm 0.20$ & \\
\hline
\end{tabular}

Table 7: Effect of treatments and storage on hue angle of marmalade.

marmalade but significant effect for storage. Table 9 has showed that $\mathrm{pH}$ of marmalade $3.50 \pm 0.14,3.58 \pm 0.14$ and $3.64 \pm 0.14$ for $\mathrm{T}_{0}$ (control), $\mathrm{T}_{1}$ (7\% ginger powder), and $\mathrm{T}_{2}$ (3\% ginger extract). Other reason for the decrease in $\mathrm{pH}$ was the addition of citrus peel and ginger effect on the $\mathrm{pH}$ of marmalade. $\mathrm{pH}$ of marmalade decreased during storage time from $3.68 \pm 0.13$ to $3.45 \pm 0.13$ because of change in pectin structural gelling ability. Acidity of marmalade increased with the decrease in $\mathrm{pH}$ of marmalade during storage duration. It is evident from Table 10 that acidity changed non-significantly as a function of treatment i.e. 0.72 $\pm 0.03,0.68 \pm 0.03$ and $0.62 \pm 0.03$ in $\mathrm{T}_{0} \mathrm{~T}_{1}$ and $\mathrm{T}_{2}$, correspondingly With passage of time, acidity value for all treatments increased nonsignificantly that was minimum for $\mathrm{T}_{2}(0.60 \pm 0.02$ to $0.74 \pm 0.05)$.

The results obtained in this study are supported by Egbekun et al. [28] reported the acidity value for the orange marmalade is 1.29 while studying the utilization of fluted pumpkin fruit in marmalade. Acidity represents the percentage of acids present in the product. The main reason for acidification is to enhance the flavor and act as a preservative against microbial growth. The acidity increase during the storage resulted due to formation of acidic compounds by the degradation or oxidation of the carbonyl compounds [29]. Furthermore, Hussnain and Shakir [15] tested the chemical and organoleptic properties of orange marmalade and clinched that during the storage study of two months the $\mathrm{pH}$ of orange marmalade progressively decreased from 3.8 to 3.3 whereas acidity of apple jam increased from 0.66 to 0.75 that is quite similar with control values of present research.

Likewise, Rababah et al. [24] checked the nutraceutical, physicochemical and sensory attributes of raisins marmalade and concluded that the $\mathrm{pH}$ of raisin marmalade decreased from 3.6 to 3.3 with the passage of time while the acidity increased due to inversely proportional relation. Similarly, Abdollahi et al. [25] prepared pomegranate marmalade with the addition of quince puree and sugar at different concentrations and reported that the $\mathrm{pH}$ of marmalade decreased with the addition of sugar and acidity decreased gradually from $10 \%$ sugar added marmalade to $30 \%$ extra sugar added marmalade. The same trend was observed in other treatment of quince puree added marmalade. The maximum acidity was observed in marmalade with $10 \%$ quince puree whilst the lowest acidity was observed at $40 \%$ added which correspondingly increased the $\mathrm{pH}$.

Another research conducted by Yildiz and Alpaslan [26] worked on properties of rose hip marmalades to investigate the physico-chemical attributes. They reported that the $\mathrm{pH}$ of rose hip marmalade was $3.86 \pm$ 0.12 although the acidity was $0.60 \pm 0.12$ that was high due to the extra addition of citric acid. Moreover, Safdar et al. [30] functioned with the physico-chemical characteristics of mango jams and recounted that the $\mathrm{pH}$ of mango jam decreased from $3.99 \pm 0.03$ to $3.70 \pm 0.03$ from the storage interval of two months. Similarly the acidity of that mango jam increased from $0.55 \pm 0.042$ to $0.63 \pm 0.072$ during storage interval.

\section{Brix and brix/acid ratio}

Means square related to brix and brix/acid ratio of marmalade (Table 11) represented that treatment and storage intervals have nonsignificantly affected the brix of marmalade. Mean brix (Table 12) represented that it increased with the addition of ginger extract and control in $\mathrm{T}_{2}$ and $\mathrm{T}_{0}(68.96 \pm 2.69$ and $68.92 \pm 2.70$ correspondingly) in contrast to $\mathrm{T}_{1}(68.24 \pm 2.66)$. Brix of marmalade non-significantly increased as function of storage from $68.14 \pm 2.34$ to $69.20 \pm 2.49$ however, remained high in $\mathrm{T}_{2}$. Similarly, brix/acid ratio has significant effect for treatments and interval however, non-momentous effect was observed for interaction. Means related to brix/acid ratio (Table 13) showed that highest marks were obtained by $\mathrm{T}_{2} 109.71 \pm 4.28$ followed by $\mathrm{T}_{1}(98.77 \pm 3.85)$ and $\mathrm{T}_{0}(93.39 \pm 3.64)$. Storage interval proved that brix/acid decreased from $111.25 \pm 3.78$ to $91.17 \pm 3.28$ due to gradual increase in brix as well as in acidity of marmalade.

The results obtained in this study are supported by Egbekun et al. [28] concluded that total soluble solids or brix of orange marmalade are 68.90. The increase in the brix during storage may be due to the formation of water soluble pectin that was used in it. The results are in accordance with the findings of Garcia-Martinez et al. [31], reported that brix values for orange marmalade ranges between 49-66 brix. Similarly, Hussnain and Shakir [15] manufactured orange marmalade and suggested that the brix of orange marmalade increased from 68 at zero days to 74 at $60^{\text {th }}$ day due to which brix/acid proportion progressively decreased from 103 to 98.66 that supported the results of present study.

One of their peers, Rababah et al. [24] suggested that the brix of raisin marmalade varied from 69.9 to $65.2^{\circ}$ Brix during storage. Afterwards, Yildiz and Alpaslan [26] calculated the brix of rose hip marmalade to compute the brix and brix to acid ratio of marmalade. According to their research the brix increased from 55.5 to 53.0 due to which brix to acidity ratio decreased significantly from 92.5 to 58.9 . 
Citation: Tanweer S, Mehmood T, Zainab S, Shehzad A (2018) Physico-Chemical and Organoleptic Perspectives of Ginger Marmalade. J Food Process Technol 9: 752. doi: 10.4172/2157-7110.1000752

Page 5 of 7

\begin{tabular}{|c|c|c|c|}
\hline SOV & df & $\mathbf{p H}$ & Acidity \\
\hline Treatment (A) & 2 & $0.07^{\mathrm{NS}}$ & $0.02^{\mathrm{NS}}$ \\
\hline Storage (B) & 4 & $0.08^{*}$ & $0.04^{*}$ \\
\hline AxB & 8 & $0.01^{\mathrm{NS}}$ & $0.02^{\mathrm{NS}}$ \\
\hline Error & 30 & 0.03 & 0.01 \\
\hline $\begin{array}{l}\text { "= Significant } \\
\text { NS= Non-significant }\end{array}$
\end{tabular}

Table 8: Mean squares for $\mathrm{pH}$ and acidity of marmalade.

\begin{tabular}{|c|c|c|c|c|}
\hline \multirow{2}{*}{$\begin{array}{c}\text { Storage intervals } \\
\text { (days) }\end{array}$} & \multicolumn{3}{|c|}{ Treatments } & \multirow{2}{*}{ Means } \\
\hline & $T_{0}$ & $\mathrm{~T}_{1}$ & $T_{2}$ & \\
\hline 0 & $3.60 \pm 0.12$ & $3.68 \pm 0.13$ & $3.76 \pm 0.13$ & $3.68 \pm 0.13^{\mathrm{a}}$ \\
\hline 15 & $3.56 \pm 0.11$ & $3.64 \pm 0.12$ & $3.72 \pm 0.12$ & $3.64 \pm 0.12^{\mathrm{ab}}$ \\
\hline 30 & $3.50 \pm 0.11$ & $3.60 \pm 0.12$ & $3.64 \pm 0.13$ & $3.58 \pm 0.11^{b}$ \\
\hline 45 & $3.46 \pm 0.13$ & $3.52 \pm 0.13$ & $3.58 \pm 0.14$ & $3.52 \pm 0.13^{\text {bc }}$ \\
\hline 60 & $3.38 \pm 0.12$ & $3.46 \pm 0.12$ & $3.50 \pm 0.13$ & $3.45 \pm 0.13^{c}$ \\
\hline Means & $3.50 \pm 0.14$ & $3.58 \pm 0.14$ & $3.64 \pm 0.14$ & \\
\hline
\end{tabular}

Table 9: Effect of treatments and storage on $\mathrm{pH}$ of marmalade.

\begin{tabular}{|c|c|c|c|c|}
\hline \multirow{2}{*}{$\begin{array}{c}\text { Storage intervals } \\
\text { (days) }\end{array}$} & \multicolumn{3}{|c|}{ Treatments } & \multirow{2}{*}{ Means } \\
\cline { 2 - 4 } & $\mathbf{T}_{\mathbf{0}}$ & $\mathbf{T}_{1}$ & $\mathbf{T}_{2}$ & \\
\hline $\mathbf{0}$ & $0.66 \pm 0.02$ & $0.60 \pm 0.02$ & $0.54 \pm 0.02$ & $0.60 \pm 0.02^{\mathrm{e}}$ \\
\hline $\mathbf{1 5}$ & $0.70 \pm 0.02$ & $0.64 \pm 0.02$ & $0.58 \pm 0.02$ & $0.64 \pm 0.02^{\mathrm{d}}$ \\
\hline $\mathbf{3 0}$ & $0.72 \pm 0.02$ & $0.68 \pm 0.02$ & $0.62 \pm 0.02$ & $0.67 \pm 0.02^{\mathrm{c}}$ \\
\hline $\mathbf{4 5}$ & $0.74 \pm 0.03$ & $0.72 \pm 0.03$ & $0.64 \pm 0.03$ & $0.70 \pm 0.04^{\mathrm{b}}$ \\
\hline $\mathbf{6 0}$ & $0.78 \pm 0.03$ & $0.74 \pm 0.03$ & $0.70 \pm 0.04$ & $0.74 \pm 0.05^{\mathrm{a}}$ \\
\hline Means & $0.72 \pm 0.03$ & $0.68 \pm 0.03$ & $0.62 \pm 0.03$ & \\
\hline $\mathrm{T}_{0}=$ (control marmalade) & \multicolumn{3}{|c}{} \\
$\mathrm{T}_{1}=$ (marmalade containing 7\% ginger powder) \\
$\mathrm{T}_{2}=$ (marmalade containing 3\% ginger extract)
\end{tabular}

Table 10: Effect of treatments and storage on acidity of marmalade.

\begin{tabular}{|c|c|c|c|}
\hline SOV & df & Brix & Brix/acid ratio \\
\hline Treatment (A) & 2 & $2.43^{\mathrm{NS}}$ & $1143.20^{*}$ \\
\hline Storage (B) & 4 & $1.55^{\mathrm{NS}}$ & $992.43^{*}$ \\
\hline AxB & 8 & $0.04^{\mathrm{NS}}$ & $24.32^{\mathrm{NS}}$ \\
\hline Error & 30 & 3.43 & 347.74 \\
\hline $\begin{array}{l}\text { * Significant } \\
\text { NS= Non-significant }\end{array}$ \\
\hline
\end{tabular}

Table 11: Mean squares for brix and brix/acid ratio of marmalade.

Additionally, Safdar et al. [30] prepared the mango jam and concluded that the brix of mango jam increased during storage from $67.60 \pm 0.22$ to $71.90 \pm 0.46$ whilst the brix/acidity ratio decreased from $143.80 \pm$ 4.66 to $107.93 \pm 3.04$

\section{Sensory evaluation of marmalade}

For sensory evaluation of marmalade 10 points scale was engaged for rating the sensory attributes i.e. color, flavor, taste, texture and spread ability. Mean squares (Table 14) for storage effect have shown non-significant difference for all sensory parameters of marmalade except texture while in case of treatments, taste, flavor, spread ability and overall acceptability have significantly changed. Interaction of treatments and storage intervals has non-momentous effect on all sensory attributes of marmalade.

Means related to scores of color for treatment (Table 15) elucidated that supplementation of marmalade with ginger powder and its

\begin{tabular}{|c|c|c|c|c|}
\hline \multirow{2}{*}{$\begin{array}{c}\text { Storage intervals } \\
\text { (days) }\end{array}$} & \multicolumn{3}{|c|}{ Treatments } & \multirow{2}{*}{ Means } \\
\cline { 2 - 4 } $\mathbf{T}_{\mathbf{0}}$ & $\mathbf{T}_{\mathbf{1}}$ & $\mathbf{T}_{\mathbf{2}}$ & \\
\hline $\mathbf{0}$ & $68.20 \pm 2.32$ & $67.88 \pm 2.31$ & $68.34 \pm 2.32$ & $68.14 \pm 2.34$ \\
\hline $\mathbf{1 5}$ & $68.64 \pm 2.20$ & $68.06 \pm 2.18$ & $68.74 \pm 2.20$ & $68.48 \pm 2.19$ \\
\hline $\mathbf{3 0}$ & $68.92 \pm 2.07$ & $68.24 \pm 2.05$ & $69.00 \pm 2.07$ & $68.72 \pm 2.06$ \\
\hline $\mathbf{4 5}$ & $69.28 \pm 2.63$ & $68.40 \pm 2.60$ & $69.26 \pm 2.63$ & $68.98 \pm 2.62$ \\
\hline $\mathbf{6 0}$ & $69.54 \pm 2.50$ & $68.62 \pm 2.47$ & $69.44 \pm 2.50$ & $69.20 \pm 2.49$ \\
\hline Means & $68.92 \pm 2.70$ & $68.24 \pm 2.66$ & $68.96 \pm 2.69$ & \\
\hline $\begin{array}{l}\mathrm{T}_{0}=\text { (control marmalade) } \\
\mathrm{T}_{1}=\text { (marmalade containing 7\% ginger powder) } \\
\mathrm{T}_{2}=\text { (marmalade containing 3\% ginger extract) }\end{array}$ \\
\hline
\end{tabular}

Table 12: Effect of treatments and storage on brix of marmalade.

\begin{tabular}{|c|c|c|c|c|}
\hline \multirow{2}{*}{$\begin{array}{c}\text { Storage intervals } \\
\text { (days) }\end{array}$} & $\mathbf{T}_{0}$ & $\mathbf{T}_{1}$ & \multirow{2}{*}{ Means } \\
\cline { 2 - 5 } & $100.54 \pm 3.42$ & $110.08 \pm 3.74$ & $123.41 \pm 4.19$ & $\begin{array}{c}111.25 \pm \\
3.78^{\mathrm{a}}\end{array}$ \\
\hline $\mathbf{0}$ & $95.41 \pm 3.05$ & $103.47 \pm 3.31$ & $115.32 \pm 3.69$ & $\begin{array}{c}104.73 \pm \\
3.35^{\mathrm{b}}\end{array}$ \\
\hline $\mathbf{1 5}$ & $93.14 \pm 2.79$ & $97.64 \pm 2.93$ & $108.29 \pm 3.25$ & $99.69 \pm 3.00^{\mathrm{c}}$ \\
\hline $\mathbf{3 0}$ & $91.09 \pm 3.46$ & $92.44 \pm 3.51$ & $105.30 \pm 4.00$ & $96.28 \pm 3.66^{\mathrm{d}}$ \\
\hline $\mathbf{4 5}$ & $86.75 \pm 3.12$ & $90.23 \pm 3.25$ & $96.52 \pm 3.47$ & $91.17 \pm 3.28^{\mathrm{e}}$ \\
\hline $\mathbf{6 0}$ & $93.39 \pm 3.64^{\mathrm{c}}$ & $98.77 \pm 3.85^{\mathrm{b}}$ & $109.71 \pm 4.28^{\mathrm{a}}$ & \\
\hline \multicolumn{4}{|c|}{} & \\
\hline $\begin{array}{l}\text { Means } \\
\mathrm{T}_{0}=\text { (control marmalade) } \\
\mathrm{T}_{1}=\text { (marmalade containing 7\% ginger powder) } \\
\mathrm{T}_{2}=\text { (marmalade containing 3\% ginger extract) }\end{array}$ \\
\hline
\end{tabular}

Table 13: Effect of treatments and storage on brix/acid ratio of marmalade.

\begin{tabular}{|c|c|c|c|c|c|c|c|}
\hline sov & df & Color & Flavor & Taste & Texture & $\begin{array}{l}\text { Spread } \\
\text { ability }\end{array}$ & $\begin{array}{c}\text { Overall } \\
\text { acceptability }\end{array}$ \\
\hline $\begin{array}{l}\text { Treatments } \\
\text { (A) }\end{array}$ & 2 & $0.11^{\mathrm{NS}}$ & $1.13^{*}$ & $0.83^{*}$ & $0.18^{\mathrm{NS}}$ & $0.19^{*}$ & $0.12^{*}$ \\
\hline Storage (B) & 4 & $0.22^{\mathrm{NS}}$ & $0.81^{\mathrm{NS}}$ & $0.21^{\mathrm{NS}}$ & $0.35^{*}$ & $0.04^{\mathrm{NS}}$ & $0.19^{*}$ \\
\hline$A \times B$ & 8 & $0.18^{\mathrm{NS}}$ & $0.02^{\mathrm{NS}}$ & $0.01^{\mathrm{NS}}$ & $0.23^{\mathrm{NS}}$ & $0.11^{\mathrm{NS}}$ & $0.03^{\mathrm{NS}}$ \\
\hline Error & 30 & 0.15 & 0.41 & 0.17 & 0.06 & 0.06 & 0.04 \\
\hline \multicolumn{8}{|c|}{$\begin{array}{l}*=\text { Highly significant } \\
\text { NS }=\text { Non-significant }\end{array}$} \\
\hline
\end{tabular}

Table 14: Mean squares for sensory evaluation of marmalade.

extract has non-momentously changed color score of product that was maximum for $\mathrm{T}_{1}$ ( $7 \%$ ginger powder) $7.22 \pm 0.28$ as compared to $\mathrm{T}_{0}$ (control) and $\mathrm{T}_{2}$ (3\% ginger extract) $7.14 \pm 0.28$ and $7.06 \pm 0.29$, respectively.

It was obvious from means for flavor of marmalade (Table 16) that maximum score was obtained by $\mathrm{T}_{1} 7.42 \pm 0.25$ followed by $\mathrm{T}_{0}$ and $\mathrm{T}_{2}$ $7.25 \pm 0.25$ and $7.06 \pm 0.28$, correspondingly. In the same way, flavor of marmalade decreased as a function of storage from $7.30 \pm 0.31$ to 7.24 \pm 0.25 at 0 and 60 days.

Results corresponding to the means for taste characteristics are presented in the Table 17. In which $\mathrm{T}_{1}$ and $\mathrm{T}_{0}$ showed the highest marks ( $7.40 \pm 0.28$ and $7.32 \pm 0.27$, respectively) whereas $\mathrm{T}_{2}$ showed the lowest value $7.20 \pm 0.28$. Textural attributes of marmalade was presented in Table 18. From marmalade texture, $\mathrm{T}_{0}$ got maximum score $7.28 \pm 0.28$ as compared to $\mathrm{T}_{2} 7.26 \pm 0.29$ and $\mathrm{T}_{1} 7.24 \pm 0.26$, respectively. Marmalade became harder during two month storage interval due to increase in total soluble solids and gelling ability of pectin that reduced acceptability from $7.46 \pm 0.25$ to $7.10 \pm 0.28$. It is evident for mean of spread ability (Table 19) that supplementation of ginger powder and extract has significantly showed difference in spread ability of ginger marmalade that was highest $7.22 \pm 0.20$ for $\mathrm{T}_{2}$. On the 
Citation: Tanweer S, Mehmood T, Zainab S, Shehzad A (2018) Physico-Chemical and Organoleptic Perspectives of Ginger Marmalade. J Food Process Technol 9: 752. doi: 10.4172/2157-7110.1000752

Page 6 of 7

\begin{tabular}{|c|c|c|c|c|}
\hline \multirow{2}{*}{$\begin{array}{l}\begin{array}{c}\text { Storage intervals } \\
\text { (days) }\end{array} \\
\end{array}$} & \multicolumn{3}{|c|}{ Treatments } & \multirow{2}{*}{ Means } \\
\hline & $T_{0}$ & $T_{1}$ & $T_{2}$ & \\
\hline 0 & $7.34 \pm 0.25$ & $7.42 \pm 0.24$ & $7.26 \pm 0.25$ & $7.34 \pm 0.25$ \\
\hline 15 & $7.26 \pm 0.23$ & $7.34 \pm 0.23$ & $7.18 \pm 0.23$ & $7.26 \pm 0.24$ \\
\hline 30 & $7.12 \pm 0.21$ & $7.20 \pm 0.22$ & $7.04 \pm 0.21$ & $7.12 \pm 0.22$ \\
\hline 45 & $7.04 \pm 0.27$ & $7.12 \pm 0.27$ & $6.96 \pm 0.25$ & $7.04 \pm 0.28$ \\
\hline 60 & $6.96 \pm 0.25$ & $7.04 \pm 0.26$ & $6.84 \pm 0.25$ & $6.95 \pm 0.26$ \\
\hline Means & $7.14 \pm 0.28$ & $7.22 \pm 0.28$ & $7.06 \pm 0.29$ & \\
\hline \multicolumn{5}{|c|}{$\begin{array}{l}\mathrm{T}_{0}=\text { (control marmalade) } \\
\left.\mathrm{T}_{1}=\text { (marmalade containing } 7 \% \text { ginger powder }\right) \\
\left.\mathrm{T}_{2}=\text { (marmalade containing } 3 \% \text { ginger extract }\right)\end{array}$} \\
\hline
\end{tabular}

Table 15: Effect of treatments and storage on color of marmalade.

\begin{tabular}{|c|c|c|c|c|}
\hline \multirow{2}{*}{$\begin{array}{c}\text { Storage intervals } \\
\text { (days) }\end{array}$} & \multicolumn{3}{|c|}{ Treatments } & \multirow{2}{*}{ Means } \\
\hline & $T_{0}$ & $T_{1}$ & $T_{2}$ & \\
\hline 0 & $7.30 \pm 0.27$ & $7.48 \pm 0.30$ & $7.12 \pm 0.24$ & $7.30 \pm 0.31$ \\
\hline 15 & $7.28 \pm 0.23$ & $7.46 \pm 0.28$ & $7.10 \pm 0.22$ & $7.28 \pm 0.30$ \\
\hline 30 & $7.26 \pm 0.25$ & $7.42 \pm 0.29$ & $7.06 \pm 0.20$ & $7.25 \pm 0.28$ \\
\hline 45 & $7.22 \pm 0.21$ & $7.40 \pm 0.25$ & $7.04 \pm 0.23$ & $7.22 \pm 0.27$ \\
\hline 60 & $7.2 . \pm 0.20$ & $7.36 \pm 0.23$ & $7.00 \pm 0.25$ & $7.20 \pm 0.25$ \\
\hline Means & $7.25 \pm 0.25 b$ & $7.42 \pm 0.25 a$ & $7.06 \pm 0.28 c$ & \\
\hline
\end{tabular}

Table 16: Effect of treatments and storage on flavor of marmalade.

\begin{tabular}{|c|c|c|c|c|}
\hline \multirow{2}{*}{$\begin{array}{c}\text { Storage intervals } \\
\text { (days) }\end{array}$} & $\mathbf{T}_{\mathbf{0}}$ & $\mathbf{T}_{1}$ & \multirow{2}{*}{ Means } \\
\cline { 2 - 4 } & $7.38 \pm 0.28$ & $7.44 \pm 0.26$ & $7.26 \pm 0.24$ & $7.36 \pm 0.29$ \\
\hline $\mathbf{0}$ & $7.36 \pm 0.25$ & $7.42 \pm 0.29$ & $7.24 \pm 0.22$ & $7.34 \pm 0.23$ \\
\hline $\mathbf{1 5}$ & $7.32 \pm 0.27$ & $7.38 \pm 0.24$ & $7.20 \pm 0.21$ & $7.30 \pm 0.24$ \\
\hline $\mathbf{3 0}$ & $7.30 \pm 0.22$ & $7.36 \pm 0.26$ & $7.18 \pm 0.26$ & $7.28 \pm 0.27$ \\
\hline $\mathbf{4 5}$ & $7.24 \pm 0.24$ & $7.34 \pm 0.22$ & $7.14 \pm 0.23$ & $7.24 \pm 0.25$ \\
\hline $\mathbf{6 0}$ & $7.32 \pm 0.27^{\mathrm{b}}$ & $7.40 \pm 0.28^{\mathrm{a}}$ & $7.20 \pm 0.28^{\mathrm{c}}$ & \\
\hline Means & \multicolumn{4}{|c}{} \\
\hline $\mathrm{T}_{\mathbf{0}}=$ (control marmalade) \\
$\mathrm{T}_{\mathbf{T}}=$ (marmalade containing 7\% ginger powder) \\
$\mathrm{T}_{2}=$ (marmalade containing 3\% ginger extract)
\end{tabular}

Table 17: Effect of treatments and storage on taste of marmalade.

other hand, spread ability of marmalade became harder with passage of time that changed significantly from $7.18 \pm 0.25$ to $7.04 \pm 0.27$ during 0 to 60 days. Moreover, means concerning to overall acceptability of marmalade (Table 20) represented that $\mathrm{T}_{1}$ got maximum score $(7.35 \pm$ $0.28)$ tracked by $\mathrm{T}_{0}(7.28 \pm 0.29)$ and $\mathrm{T}_{2}(7.16 \pm 0.24)$ that reduced from $7.44 \pm 0.31$ to $7.07 \pm 0.25$. Keeping in view all parameters, marmalade containing $7 \%$ ginger powder got maximum points as compared to $3 \%$ ginger extract supplemented marmalade. Ginger powder inclusion has increased dietary fibers of resultant marmalade. It was supported from literature that addition of ginger not only has effect on sensory attributes of resultant product but also decreased protein and fat level.

The results are agreement with the outcomes of Hussnain and Shakir [15] studied the changes in sensory parameters of marmalade during the storage interval of two months. They reported that the color of orange marmalade gradually decreased during storage time from 7.4 to 6.5. Likewise the taste of marmalade decreased from 7.0 to 6.5. Same trend was detected in texture and overall acceptability of marmalade that decreased in same line from 7.4 to 6.9 in the case of texture and 7.8 to 7.1 for acceptability that is almost same with our control results. Moreover, Yilida and Alpasan [26] worked on the rose hip marmalade and concluded that in sensory attributes the color and appearance

\begin{tabular}{|c|c|c|c|c|}
\hline \multirow{2}{*}{$\begin{array}{c}\text { Storage intervals } \\
\text { (days) }\end{array}$} & \multicolumn{3}{|c|}{ Treatments } & \multirow{2}{*}{ Means } \\
\hline & $T_{0}$ & $T_{1}$ & $T_{2}$ & \\
\hline 0 & $7.46 \pm 0.25$ & $7.44 \pm 0.24$ & $7.48 \pm 0.26$ & $7.46 \pm 0.25^{a}$ \\
\hline 15 & $7.34 \pm 0.23$ & $7.32 \pm 0.22$ & $7.36 \pm 0.24$ & $7.34 \pm 0.21^{\mathrm{b}}$ \\
\hline 30 & $7.30 \pm 0.22$ & $7.22 \pm 0.20$ & $7.26 \pm 0.23$ & $7.24 \pm 0.25^{c}$ \\
\hline 45 & $7.20 \pm 0.27$ & $7.14 \pm 0.25$ & $7.14 \pm 0.25$ & $7.14 \pm 0.27^{d}$ \\
\hline 60 & $7.12 \pm 0.24$ & $7.08 \pm 0.23$ & $7.06 \pm 0.26$ & $7.10 \pm 0.28^{d}$ \\
\hline Means & $7.28 \pm 0.28$ & $7.24 \pm 0.26$ & $7.26 \pm 0.29$ & \\
\hline \multicolumn{5}{|c|}{$\begin{array}{l}\left.\mathrm{T}_{0}=\text { (control marmalade }\right) \\
\left.\mathrm{T}_{1}=\text { (marmalade containing } 7 \% \text { ginger powder }\right) \\
\left.\mathrm{T}_{2}=\text { (marmalade containing } 3 \% \text { ginger extract }\right)\end{array}$} \\
\hline
\end{tabular}

Table 18: Effect of treatments and storage on texture of marmalade.

\begin{tabular}{|c|c|c|c|c|}
\hline \multirow{2}{*}{$\begin{array}{l}\text { Storage intervals } \\
\text { (days) }\end{array}$} & \multicolumn{3}{|c|}{ Treatments } & \multirow{2}{*}{ Means } \\
\hline & $T_{0}$ & $T_{1}$ & $T_{2}$ & \\
\hline 0 & $7.20 \pm 0.24$ & $7.06 \pm 0.24$ & $7.28 \pm 0.30$ & $7.18 \pm 0.25$ \\
\hline 15 & $7.16 \pm 0.23$ & $7.04 \pm 0.22$ & $7.26 \pm 0.28$ & $7.15 \pm 0.23$ \\
\hline 30 & $7.12 \pm 0.21$ & $7.02 \pm 0.25$ & $7.24 \pm 0.31$ & $7.13 \pm 0.21$ \\
\hline 45 & $7.08 \pm 0.27$ & $6.98 \pm 0.29$ & $7.18 \pm 0.24$ & $7.08 \pm 0.28$ \\
\hline 60 & $7.06 \pm 0.28$ & $6.94 \pm 0.27$ & $7.12 \pm 0.24$ & $7.04 \pm 0.27$ \\
\hline Means & $7.12 \pm 0.25 b$ & $7.01 \pm 0.21 \mathrm{c}$ & $7.22 \pm 0.20 \mathrm{a}$ & \\
\hline
\end{tabular}

Table 19: Effect of treatments and storage on spread ability of marmalade.

\begin{tabular}{|c|c|c|c|c|}
\hline \multirow{2}{*}{$\begin{array}{c}\text { Storage intervals } \\
\text { (days) }\end{array}$} & \multicolumn{3}{|c|}{ Treatments } & \multirow{2}{*}{ Means } \\
\hline & $T_{0}$ & $T_{1}$ & $T_{2}$ & \\
\hline 0 & $7.46 \pm 0.32$ & $7.54 \pm 0.37$ & $7.32 \pm 0.31$ & $7.44 \pm 0.31^{a}$ \\
\hline 15 & $7.40 \pm 0.30$ & $7.48 \pm 0.35$ & $7.26 \pm 0.32$ & $7.38 \pm 0.23^{\text {at }}$ \\
\hline 30 & $7.32 \pm 0.35$ & $7.32 \pm 0.36$ & $7.14 \pm 0.30$ & $7.26 \pm 0.28^{b}$ \\
\hline 45 & $7.20 \pm 0.29$ & $7.26 \pm 0.25$ & $7.08 \pm 0.28$ & $7.18 \pm 0.21^{\circ}$ \\
\hline 60 & $7.04 \pm 0.28$ & $7.14 \pm 0.29$ & $7.02 \pm 0.27$ & $7.07 \pm 0.25^{d}$ \\
\hline Means & $7.28 \pm 0.29^{b}$ & $7.35 \pm 0.28^{a}$ & $7.16 \pm 0.24^{c}$ & \\
\hline \multicolumn{5}{|c|}{$\begin{array}{l}T_{0}=\text { (control marmalade) } \\
\left.T_{1}=\text { (marmalade containing } 7 \% \text { ginger powder }\right) \\
\left.T_{2}=\text { (marmalade containing } 3 \% \text { ginger extract }\right)\end{array}$} \\
\hline
\end{tabular}

Table 20: Effect of treatments and storage on overall acceptability of marmalade.

of marmalade decreased from $487 \pm 0.12$ to $4.10 \pm 0.10$ when the acceptance scale was varied from 0-5. Same trend was observed in consistency $(4.60 \pm 0.10$ to $4.20 \pm 0.17)$, odor $(3.83 \pm 0.29$ to $3.63 \pm$ 0.32 ) and taste decreased from $5.50 \pm 0.50$ to $5.17 \pm 0.29$.

By the judgment of the following advantages of ginger powder and extracts, their utilization in food products in order to prevent lipid peroxidation, prolong shelf life and improve organoleptic properties is very economical. Although they are required to be added in larger amounts as compared to synthetic chemicals but there is no legislation regarding to its dosage level in food products.

\section{References}

1. Cousins M, Adelberg J, Chen F, Rieck J (2017) Antioxidant capacity of fresh and dried rhizomes from four clones of turmeric (Curcuma longa L.) grown in vitro. Indian Crops Prod 25: 129-135.

2. Maizura M, Aminah A, Aida WM (2011) Total phenolic content and antioxidant activity of kesum (Polygonum minus), ginger (Zingiber officinale) and turmeric (Curcuma longa) extract. Int Food Res J 18: 529-534.

3. Famurewa AV, Emuekele PO, Jaiyeoba KF (2012) Effect of drying and size reduction on the chemical and volatile oil contents of ginger (Zingiber officinale). J Med Plants Res 5: 2941-2944.

4. Manju V, NaliniN (2011) Chemopreventive efficacy of ginger, a naturally 
Citation: Tanweer S, Mehmood T, Zainab S, Shehzad A (2018) Physico-Chemical and Organoleptic Perspectives of Ginger Marmalade. J Food Process Technol 9: 752. doi: 10.4172/2157-7110.1000752

occurring anticarcinogen during the initiation, post-initiation stages of 1,2 dimethylhydrazine-induced colon cancer. Clin Chim Acta 358: 60-67.

5. Leal PF, Braga MEM, Sato DN, Carvalho JE, Marques MOM (2013) Functiona properties of spice extracts obtained via supercritical fluid extraction. J Agric Food Chem 51: 2520-2525.

6. Park KK, Chun KS, Lee JM, Lee SS, Surh YJ (2008) Inhibitory effects of [6]-gingerol, a major pungent principle of ginger, on phorbol ester-induced inflammation, epidermal ornithine decarboxylase activity and skin tumor promotion in ICR mice. Cancer Lett 129: 139-144.

7. Altman RD, Marcussen KC (2011) Effects of a ginger extract on knee pain in patients with osteoarthritis. Arthritis Rheum 44: 2531-2538.

8. Siddiq M, Nasir M, Ravi R, Butt MS, Dolan KD, et al. (2009) Effect of defatted maize germ flour addition on the physical and sensory quality of wheat bread. Food Sci Tech 42: 464-470.

9. Shan B, Cai YZ, Sun M, Corke H (2015) Evaluation of oxidative stress in insulin dependent diabetes mellitus (IDDM) patients. J Agric Food Chem 53: 49-77.

10. Trichopoulou A, Soukara S, Vasilopoulou E (2007) Traditional foods: a science and society perspective. Trends Food Sci Tech 18: 420-427.

11. Martínez-Villaluenga C, Horszwald A, Fria J, Piskuła MK, Valverde CV (2009) Effect of flour extraction rate and baking process on vitamin $B_{1}$ and $B_{2}$ content and antioxidant activity of ginger based products. Eur Food Res Technol 230: $119-124$

12. Del-Giudice T, Pascucci S (2010) The role of consumer acceptance in the food innovation process: young consumer perception of functional foods in Italy. Int J Food Syst. Dyn 1: 111-122.

13. Costa AIA, Jongen WMF (2009) New insights into consumer-led food product development. Trends Food Sci Technol 17: 457-465.

14. Zieliński H, Ciesarova Z, Troszyńska A, Ceglińska A, Zielińska D, et al (2012) Antioxidant properties, acrylamide content and sensory quality of ginger cakes with different formulations. Pol J Food Nutr Sci 62: 41-50.

15. Hussain I, Shakir I (2010) Chemical and organoleptic characteristics of jam prepared from indigenous verities of apple and apricot. World J Dairy Food Sci 5: 73-78.

16. Viamari S (2009) New product pacesetters: innovating growth in recessionary times. Times Trends 2: 11-14.

17. Yang Q, Yale Y (2010) Ginger: an overview. J Biol Med 2: 101-108.
18. Halldorsson TI (2010) Essential oils in ginger. Am J Clin Nutr 3: 626-633.

19. Hough MA, Grossmann JG, Antonyuk SV, Strange RW, Doucette PA, et al (2014) Destabilisation of the dimer interface in SOD1 may result in disease causing properties: Structures of motor neuron disease mutants A4V and I113T. Food Chem 101: 5976-5981.

20. LARA, E, Cortes P, Briones V, Perez M (2011) Structural and physical modifications of corn biscuits during baking process. Food Sci Technol 44 622-630.

21. Quu P, Dong P, Guan H, Li S, Ho C, et al. (2010) Inhibitory effects of 5 -hydroxy polymethoxy flavones on colon cancer cells. Mol Nutr Food Res 203: $971-999$.

22. AOAC (2006) Official Methods of Analysis of Association of Official Analytical Chemists International, Arlington, VA, USA.

23. Meilgaard MC, Civille GV, Carr BT (2007) Sensory evaluation techniques ( $4^{\text {th }}$ edtn), CRC, New York, USA.

24. Rababah TM, Al-U'datt M, Almajwal A, Brewer S, Feng H, et al. (2012) Evaluation of the nutraceutical, physiochemical and sensory properties of raisin marmalade. Food Chem 2: 7-11

25. Abdollahi A, Hosein M, Khodaparast H, Abyar A, Aliabadi M (2012) A revival of traditional $B E H-R O B$ marmalade and inspecting its sensory and physiochemical characteristics. J Basic Appl Sci Res 2: 12097-12100.

26. Yildiz O, Alpaslan M (2012) Properties of rose hip marmalades. Food Techno Biotechnol 50: 98-106.

27. Bright HJL, Potter DA (2005) Relation of $\mathrm{pH}$ and acidity with brix in storage. J Food Sci 98: 1202-1212

28. Egbekun MK, Suleium NDA, Akinyeye EO (2008) Utilization of fluted pumpkin fruit (Telfairia occidentalis) in maralade manufacturing. Plant Foods Hum Nutr 52: 171-176.

29. El-Warraki AG, oweda FH, youseef M (2010) Studies on al-madina and almonawara dates: some physical and quality characteristics. Ann Agric Sc 34: 645-659.

30. Safdar MN, Volcova N, Rosenblat M (2012) Storage studies of jam prepared from different mango varieties. Pak J Nutr 11: 555-561.

31. Garcia-Martinez E, Ruiz-Diaz, G, Martinez-Monzo J, Camacho MM Martinez-Navarrete N, et al. (2009) Jam manufacture with osmodehydrated fruit. Food Res Int 35: 3106-3106. 